\title{
The Burned-over District
}





\section{The Burned-over District}

THE SOCIAL AND INTELLECTUAL HISTORY

OF ENTHUSIASTIC RELIGION IN

WESTERN NEW YORK, 1800-1850

\section{WHITNEY R. CROSS}

\section{Cornell University Press}

ITHACA AND LONDON 


\section{Copyright $195^{\circ}$ by Cornell University}

All rights reserved. Except for brief quotations in a review, this book, or parts thereof, must not be reproduced in any form without permission in writing from the publisher. For information address

Cornell University Press, 124 Roberts Place, Ithaca, New York 14850.

First published 1950 by Cornell University Press.

Published in the United Kingdom by Cornell University Press Ltd., Ely House, 37 Dover Street, London $W_{1} X_{4} \mathrm{HQ}$.

First printing, Comell Paperbacks, 1982.

International Standard Book Number o-8014-9232-7

Library of Congress Catalog Card Number 50-12161

Printed in the United States of America

This book is a print-on-demand volume.

It is manufactured using toner in place of ink.

Type and images may be less sharp than the same

material seen in traditionally printed

Cornell University Press editions. 
For Ruth 
For precious, immortal soul, I pray thee consider: thou art but a man, a worm of dust as well as I and the list of thy fellow mortals tabernacling here in clay. Thy breath is in thy nostrils. Remember thou art still in the body, liable to temptations as others are, and therefore not sufficient in and of thyself to determine what shall be done with offenders. For if thou canst determine [sentence?] upon one, thou may as well upon all thou imaginest to be guilty, whether they be so or not. . . - MEhitable SMith to ABNER BROWNell, AUGuST 90, 1782. 